\title{
SYMBOLISM IN KATHERINE ANNE PORTER'S SHORT STORY ROPE
}

\author{
Park S. Yoanna \\ Universitas Negeri Surabaya \\ kyksanjo@naver.com
}

\begin{abstract}
This study aims to examine the use of a symbol and narration technique in Katherine Anne Porter's short story Rope. The story is about a married couple who gets into an argument due to a bundle of rope. This study examines how the author describes the psychological state of the couple through their reaction over the rope. The data sources are the short story Rope and related articles. The data was collected by close reading. The collected data are analyzed by applying symbolism theory and examining the narration technique. The findings show that the argument over the rope reveals the wife's hidden frustrations and her husband's inability to understand her troubles.
\end{abstract}

Keywords: Symbol; Rope; Frustration; Katherine Anne Porter; Narration

\section{INTRODUCTION}

Writers use literary devices and techniques to convey their ideas accurately. A symbol is one of the devices that broadens the imagination of readers. A symbol can be a word, an object, an image, or an action that represent something more than its literal meaning. "The literary symbol is an analogy for something unstated, consists of an articulation of verbal elements that, going beyond reference and the limits of discourse, embodies and offers a complex of feeling and thought" (Tindall, 1955:12).

This paper studies the symbolism in the short story entitled Rope written by Katherine Anne Porter. The author, Katherine Anne Porter (1890-1980) is reputed as one of America's distinguished short-story writers.She was awarded Guggenheim Fellowship, Book-of-MonthClub, National Book Award, and Pulitzer Award.

The story Rope is about a couple and the heated argument between the husband and the wife who fight over a rope and coffee. The initial argument about a rope and coffee turns into a serious quarrel. As the story unfolds, the root of their fight is revealed.

On the third day of their move to the country, the young couple argues. While she is cleaning up at home, he walks four miles away to a town to buy groceries. But, he forgets the coffee that she asked him to buy and buys an unnecessary bundle of rope instead. Moreover, all the eggs that are placed under the rope are broken, and she becomes even angrier. The wife 
nags her husband and he makes an excuse. The rope triggers a vicious cycle of quarrel. At the end of the fight, she goes into hysteria, and her surprised husband tries to calm her. He eventually goes back to town to buy coffee and to exchange the rope for something practical. When he exhaustedly arrives home with coffee, she has gained calmness and is waiting for him. He didn't exchange the rope for something else but brought it back home. However, she reconciles with him by telling him that he can keep the rope if he really wants it.

It is noticeable that for the majority of the story the wife is resentful towards her husband. The issue of rope and coffee is a secondary cause of her resentment. Her bitterness is caused by several issues. Throughout the story, the wife appears to be struggling with housework; she takes great care to keep the house neat and tidy. She does not stop thinking about chores that need to be done, while her husband is indifferent to housework. She also feels that her husband is not faithful to her because he once had a romantic relationship with another woman. Her anxiety stems from her psychological insecurity.

Porter's reputation rests on her portrait of the frustrations and tragic situations that ordinary people experience as they live. Most of Porter's works are related to her own experiences ( $\mathrm{R}$ Wang \& J Liu, 2016:1). Unrue says in the book The Truth \& Vision in Katherine Anne Porter's Fiction (2009) that Porter depicts the complications and contradictions of human nature. The story Rope effectively describes the hidden frustration of a married couple that is caused by lack of communication by presenting a bundle of rope as a symbol.

\section{REVIEW OF LITERATURE}

Unrue (2009) quotes Robert Penn Warren that "the more we steadily inspect the work of Katherine Anne Porter, the more we see the inner coherence the work as a deeply imaginative confrontation or a sensibility of genius with the chiaroscuro of modern civilization." That coherence, Warren cites, is made up of Porter's central philosophy and style, both of which grew out of her experience (218). Porter delivers her philosophy through Symbolism in many of her works.

Alfred North Whitehead, an English mathematician and philosopher, explains that symbolism represents the human imaginations and thoughts. According to Whitehead "the word is a symbol, and its meaning is constituted by the ideas, images, and emotions, which it raises in the mind of the hearer" (1927:2). Symbols enable authors to convey their ideas or messages from multiple perspectives. 
$\mathrm{Ru}$ Wang (2010) quotes Porter in her article Symbolism: The Main Artistic Style of Katherine Anne Porter's Short Stories as follows:

symbolism happens of its own self and it comes out of something so deep in your own consciousness and your own experience that I don't think that most writers are at all conscious of their use of symbols. I never am until I see them. They come of themselves because they belong to me, and have meaning to me, but they come of themselves. I have no way of explaining them... and I suppose you don't invent symbolism (95).

A thesis entitled Symbolism in the Short Stories of Katherine Anne Porter by Smith, M P. (1959) explains symbolism as follows:

men use symbolism to express the spiritual, the intangible. Some things are so well established by tradition as symbols that they can function as symbols with very little effort on the part of the writer who uses them. Other things will function as symbols only if the writer establishes them as such for a particular story. A writer can use almost anything as a symbol.

\section{DISCUSSIONS OF THE MAIN THEMES}

This paper deals with one of Porter's short stories entitled Rope that uses a rope as a symbol to represent the unseen disappointment that a young couple experiences. A symbol is a communication tool that is intended to represent or stand for something, usually an intangible concept. Merriam-Webster dictionary defines that a symbol is "something that stands for or suggests something else by reason of relationship, association, convention or accidental resemblance." It is "a visible sign of something invisible."

Ru Wang (2010) says that a symbol can be an action, a sound, a thing, or a movement. It can be felt with five senses; it can be seen, heard, felt, tasted, or touched. A regular symbol carries a common interpretation. A white dove, for example, is a regular symbol of peace. A word 'Mozart' symbolizes a musical genius. A four-leaf clover is a regular symbol of luck. A literary symbol has a possibility of multiple interpretations. For example, 'mountain' could be used as nature in one context and an obstacle in another. 'Sea' could signify a peaceful place, a new world, or a destructive force. "In a certain sense, writers use symbols because all men are symbolistic by nature. We tend to find in objects and happenings significance over and above the meaning of the object of a motion itself" (Smith, 1959:2). According to Smith (1959), a badge is a piece of decorated metal, and it also symbolizes authority. A trophy is a decorative cup and it also represents victory. If someone clenches his fist, it means that he is preparing for a fight or he is showing his anger. Badge and the clenching of the fist are symbols because they are the signs of something beyond themselves.

In the story Rope, Porter unfolds the story of a young married couple who comes to realize their differences as a result of an argument over a piece of rope that the husband 
purchases. The husband refuses to exchange the rope for something more practical. The rope becomes a symbol of his pride. From the wife's point of view, however, buying the unnecessary rope shows his "impractical aspect" and his "uncooperative attitude" at home.

Apart from the individual dimension, the rope also has a universal meaning. The rope symbolizes 'marriage itself' as it can be seen from the expression 'tying the knot'. The rope is twisted which symbolizes the interweaving of all of the complex emotions that are involved in marriage. The serious struggle caused by the trivial issue of buying a rope and forgetting coffee shows the deep-rooted distrust between the couple that has not been revealed until then.

The husband and the wife in this story have not been named, nor are they specifically described. Porter used 'he' and 'she' to refer to the couple. There is nothing known about the location of the story. It is presumed that the house they move in is located somewhere in the countryside and four miles away from the town with no transportation. This vagueness suggests that the arguments of this couple are a typical one that can occur among any young couple, in any place, rather than a story of a specific person that takes place in a certain place. Porter used ambiguity to evoke sympathy from ordinary young couples.

Porter used the technique of narrated monologue to express the lack of communication between the two people. The narrator's monologue replaces the characters' words and represents the characters' thought. The narrator describes the event from the perspective of a third party. Dora Zhang (2017) says in her symposium paper that narrated monologue is an elegant way to represent a character's thoughts, speech, and perceptions directly without the intervention of a narrator who reports these. Zhang quotes Dorrit Cohn as follows:

narrated monologue is a version of the character's thoughts with his own words and attitudes but set in the syntax of a third-person narration. It creates ambiguity as to whether it is actual speech or merely thought which is being depicted (2017).

From the husband's perspective, the rope symbolizes masculine country work. Although he buys a rope, in fact, he seems not to be familiar with country living. The monologue describes him as follows:

he thought there were a lot of things a rope might come in handy for... it would be useful, twenty-four yards of rope, there were hundreds of things, he couldn't think of any at the moment, but it would come in.

The couple does not have direct conversations even during the wrangling. They don't see what the other party is thinking. But, thanks to the narrator, readers can understand the characters' feelings and the cause of their argument. Neither of them truly listens to the other. 
The monologue switches its stance from one character to another and reveals the hidden contents of the message that each of them wants to deliver to the other party.

When the husband comes back from the town, she does not ask him "do you bring the coffee?" Instead, the monologue says "had he brought the coffee?" On the scene where the eggs are broken, the wife does not ask him directly. Instead, there is a monologue: "what had he put on top of them? hadn't he known eggs mustn't be squeezed? The husband also says indirectly "Squeezed, who had squeezed them?" The readers feel as if they are watching a scene from the distance without being emotionally engaged in the fight of the couple.

The couple is caught up in a serious argument. However, their voices are not directly heard. The wife is angry because of the rope, but her husband thinks that he bought it to exercise the freedom of being able to buy such a thing, even though the rope has no urgent need. His thought is not delivered to his wife. While the argument is turning into a quarrel, the rope is repeatedly mentioned as the main culprit; it sits on some eggs and crushes them; it will occupy some space in the kitchen where the wife puts everything neat and tidy. His inconsiderate and selfish attitude upsets the wife. Jane K. DeMouy explains that the argument stems from the lack of communication:

She cannot express her dissatisfaction plainly and directly. She deals in subterfuge, which is why the rope becomes such a bone of contention. The quarrel must reach a certain pitch before she will name her specific complaints, but a close reading of her comments reveals the way her irritation moves rapidly from one detail to the next, baffling her husband" (requote: Shim B.J., 1991:11).

In this story, the wife starts the fight and ends the fight. Her husband seems to be the victim of her irrational nagging. The observation of their attitudes shown through the monologues reveals that she is discouraged by unfavorable situations and he does not understand her psychology. The rope triggers the explosion of accumulated complains. Therefore, the basic theme of this story is 'wife's frustration' caused by the lack of understanding and communication.

There are reasons for her frustration. The couple has different personalities. She wants to keep her house tidy. All things must be in their place, and the work that has been planned must be done. Her eyes are full of work. She has to clean the windows, to vent the bed mattress, but it's too much for her to do alone. She desperately wants help from her husband, but he does not understand her troubles at all. To him, her habit of arranging things seems insane and silly. He thinks she is a hopeless melancholiac, a pathetic woman who makes herself a complete fool. The monologue says: 
well, in that case, he wanted to know what the hammer and nails were doing up there? And why had she put them there when she knew very well he needed that hammer and those nails upstairs to fix the window sashes? she simply slowed down everything and made double work on the place with her insane habit of changing things around and hiding them in the middle of the bedroom floor where they could step on them in the dark. And now if he didn't clear the whole mess out of there she would throw them down the well. She was sure she begged his pardon, and if she had had any reason to believe he was going to fix the sashes this summer she would have left the hammer and nails right where he put them."; "did she realize she was making a complete fool of herself? And what did she take him for, a three-year-old idiot?"; "she could work herself into a fury about simply nothing. Terrible she doesn't have an ounce of reason.

She is a cautious and detailed person but lacks flexibility. When the eggs break unexpectedly, she is embarrassed. She has to use broken eggs for dinner instead of making a meat dish because there is no cool place that keeps the eggs fresh. She does not like changing her menu plan. Her monologue says "Well, anyhow, she could see one thing plain: no eggs for breakfast. They'd have to scramble them now, for supper. It was too damned bad. She had planned to have steak for supper."

They are financially difficult; the house is half empty; their home is far from the railway station; they do not have cars so he has to walk four miles to the town to buy groceries; there is no ice to preserve fresh food; she has no a penny in her pocket. The couple is not equal in terms of economy. The monologue says:

she knew as well as he did that his work brought in the regular money, hers was only occasional, if they depended on what she made --- and she might as well get straight on this question once for all. The question was, when both of them were working on their own time, was there going to be a division of the housework, or wasn't there? She merely wanted to know, she had to make her plans. Why, he thought that was all arranged. It was understood that he was to help. Hadn't he always, in summers?

Their living costs depend mainly on the husband's income. The husband thinks that his wife should be aware of this fact. So, when his wife complains about the fair share of the house works, he says he is doing his portion. In other words, since he regularly makes money, he thinks, she should be in charge of housework. At this point, the woman becomes hysterical.

Another problem with this couple is that the husband was once unfaithful to his wife. Before the couple moved to the countryside, the husband remained in the city to make extra money, and his wife came alone to the countryside. During this brief period, he had a light fun with another woman and the wife noticed it. As the wife brought up this matter the argument heightened. 
Evidently, the wife is overwhelmed by the complication of several trivial issues. The complication gets serious due to discrepancies in the personalities of the two people. The husband is angry at his wife because she is more concerned about a piece of rope than his feelings. Even though he has a sore on his heel, as a gesture of reconciling, he goes to the town to buy coffee and exchange the rope for a more practical item. While her husband is away, she tries to find a settlement in her own way. She prepares dinner and waits for her husband. Instead of making a new commotion, she allows him to keep the rope and apologizes for the disruption caused by the coffee. They both try to amend the tense situation. The couple's fighting ends without further complication. Even though their dispute is settled, the cause of the conflict is not fundamentally resolved. The issues of economic difficulties and personality differences remain. The rope was the cause of quarrel, but still, he brought it back. This action symbolizes that he will continue asserting his pride at home.

"He knew how she was, didn't he? Sure he knew how she was." This sentence contains ironic nuance. If he thinks that she is upset simply because of coffee, this means that he does not know her cumulative grievance and psychological state. It is also a problem if he knows her unstable psychological state and does not try to eliminate the cause of her anxiety. The narrator remains detached from the commentary, and the reader must accept the ambiguity of the situation.

The story begins pessimistically but there is a sense of optimism at the end of the story.

He was a love, she firmly believed, and if she had had her coffee in the morning, she wouldn't have behaved so funny .. . There was a whippoorwill still coming back, imagine, clear out of season, sitting in the crab-apple tree calling all by himself. Maybe his girl stood him up. Maybe she did. She hoped to hear him once more, she loved whippoorwills.

The whippoorwill birds are known to be loyal to their family. Porter mentions whippoorwills to symbolize that they still have hope.

\section{CONCLUSION}

In the story, Porter delineates circumstances in which a wife is caught in an unhappy marriage and completely frustrated by the situation surrounding her. The wife experiences financial distress and anxiety over her unfaithful husband and personality conflict. The story that is based on the quarrel of a married couple shows that a small dispute that happens in everyday life can be an opportunity to express cumulative complaints. The trivial argument about coffee and rope becomes a serious squabbling. The irony is that neither party cares for the other, any more than they care about the useless rope. 
In Rope, Porter illustrates frustration and disappointment hidden in everyday life. In the story, a rope becomes a symbolic chain that joins them in misery.

Thus, this paper examined how Katherine Anne Porter used symbolism to express the delicate aspects of human nature in her short story.

\section{REFERENCES}

Merriam-Webster. (2018). Symbol. Retrieved January 10, 2018 from https://www.merriamwebster.com/dictionary/symbol

Porter, K. A. Rope.RetrievedJanuary 10, 2018from http://shortstorymasterpieces.altervista.org /porterrope.html

Shim, B. J. (1991). A Thematic Study of Katherine Anne Porter's Fiction. Seoul: Sookmyong University

Smith, M P. (1959). Symbolism in the Short Stories of Katherine Anne Porter. Chicago: Loyola University

Tindall, W Y. (1955). The Literary Symbol. New York: Columbia University Press

Unrue D H. (2009). Truth \& Vision in Katherine Anne Porter's Fiction. Athens: The University of Georgia Press

Wang, R. (2005 September). The Language Style of Katherine Anne Porter's Short

Stories.Harbin: US-China foreign Language, Vol. 3, No.9. Retrieved January 16, 2018 fromhttp://ibrarian.net/navon/paper/The_Language_Style_of_Katherine_Anne_Porter_s Sho.pdf?paperid=6354103.pdf

-(2010 September). Symbolism---The Main Artistic Style of Katherine Anne Porter's Short Stories. Harbin: Harbin Medical University English Language Teaching, Vol. 3, No. 3. Retrieved January 16, 2018 from https://files.eric.ed.gov/fulltext/EJ1081825.pdf

Wang, R and Liu, J. (2016). An Analysis of Autobiographical Narrative Techniques in Katherine Anne Porter's Short Stories.Nanchang: Journal of Language, Linguistics and Literature, Vol. 2, No. 3. Retrieved January 16, 2018 fromhttp://files.aiscience.org/journal/article/pdf/70360051.pdf

Wellek, René. (2011). Theory of literature. New York: Harcourt, Brace

Whitehead, A N. (1927). Symbolism Its Meaning and Effect. Digital Library of India item 2015.166010

Zhang, D. (2017). What is Free Indirect Discourse Now?Department of Comparative Literature, University of California, Berkeley. Retrieved January 10, 2018 fromhttp://complit.berkeley.edu/featured/what-is-free-indirect-discourse-now/ 